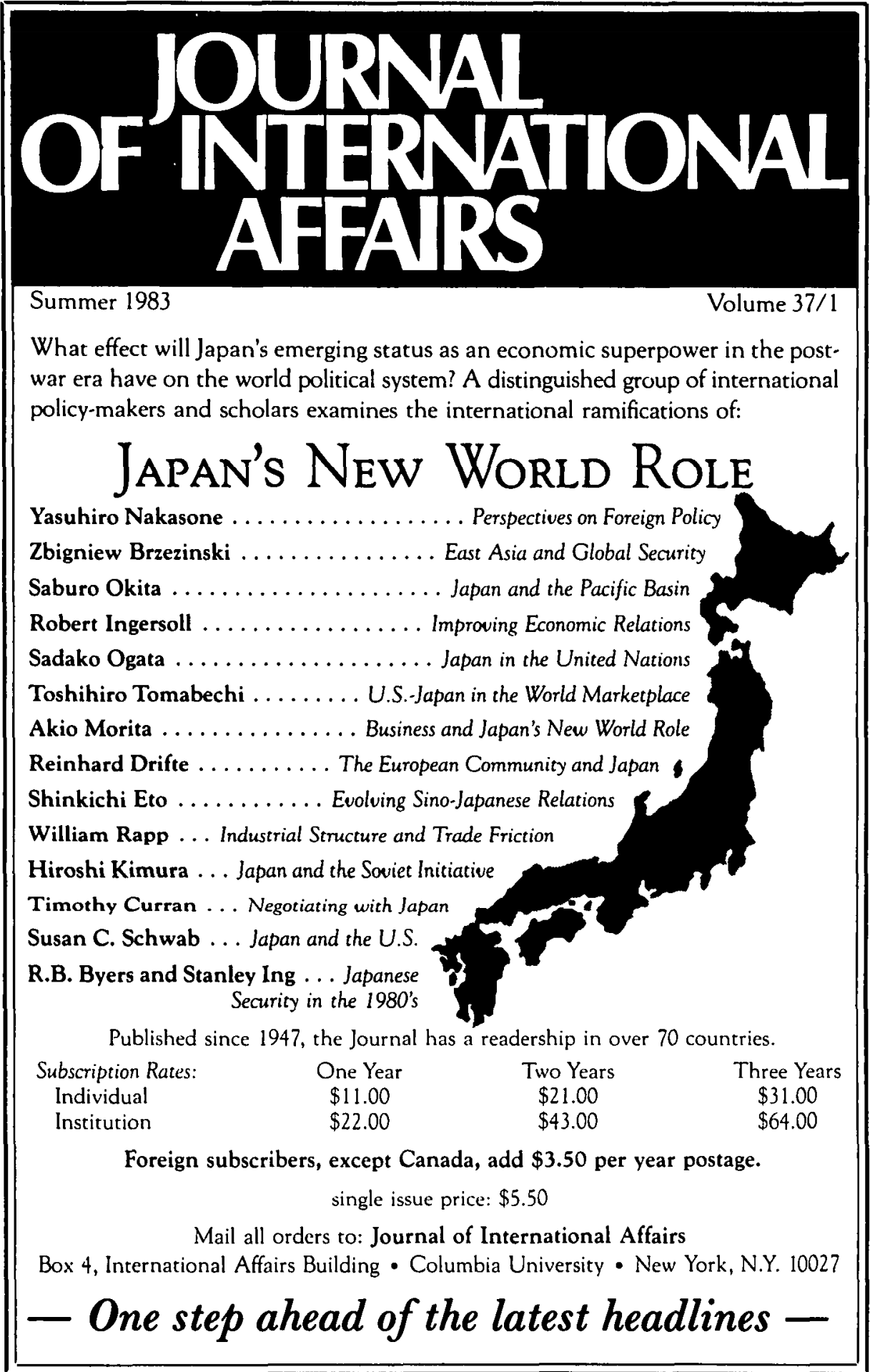




\section{Lectures on International Trade}

\section{Jagdish N. Bhagwati and T. N. Srinivasan}

This textbook by two eminent theorists of international trade presents the most integrated and ambitious treatment of the subject available to date. Its thirtyfour chapters focus on pure rather than monetary theory. Grouped in four parts, they address: alternative models and theories explaining the trade pattern; tariffs, quotas, and transfers; the theory of trade and welfare; trade and growth, two-ness and duality, cost benefit analysis and uncertainty.

July 464 pp. 164 illus. $\$ 24.95$

\section{Third World Multinationals}

The Rise of Foreign Investment from

Developing Countries

Louis T. Wells, Jr.

Third-World Multinationals explores the question of why firms based in developing countries have chosen to invest in branches, joint ventures, and whollyowned subsidiaries overseas rather than simply export goods or enter into licensing arrangements abroad. The author is Herbert F. Johnson Professor of International Management at the Harvard Business School.

April $\quad 224 \mathrm{pp} . \quad \$ 25.00$

\section{Banking on the Poor}

\section{The World Bank and World Poverty}

Robert L. Ayres

"Tails are not allowed to wag dogs in Robert Ayres' book. He stands squarely in the middle ground, adopting 'a realist's defense of the Bank as a reformist institution.' .. . Under [his] microscope, the World Bank emerges with a kind of low-key credit that a cautious reformist intends as high praise. His book is thorough, his approach measured: there are no conspiracies, no monoliths, no big failures (and no big successes either). It sounds quite plausible, and it is." -Rupert Pennant-Rea, The Washington Post Book World

1983304 pp. $\$ 17.50$

\section{Original in paperback}

\section{Economic Interdependence and Flexible Exchange Rates}

edited by Jagdeep $S$. Bhandari and Bluford H. Putnam, with Jay H. Levin

The eighteen essays (all but two are original) in this book explore what the shift from fixed to flexible exchange rates has meant for world economic interdependence and seek to clarify what has become an extremely complex system.

1983560 pp. $\$ 15.00$

(Cloth $\$ 30.00$ ) 


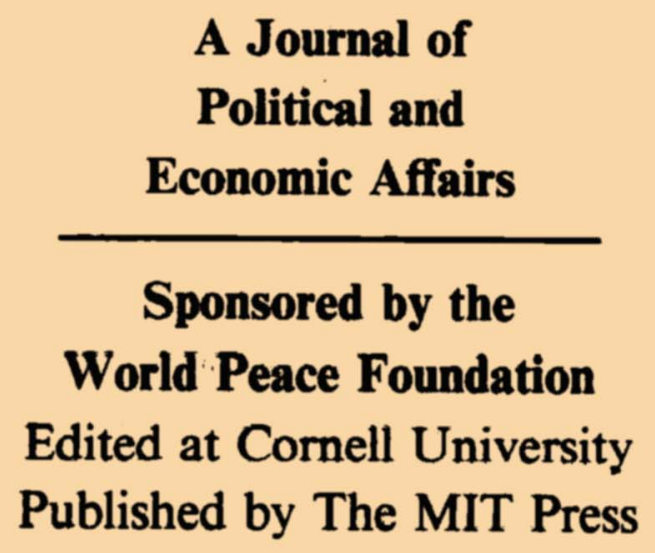

